\title{
Women in development: A critical analysis
}

\section{Gina Koczberski}

Third World Quarterly; Sep 1998; 19, 3; Academic Research Library pg. 395

Third World Quarterly, Vol 19, No 3, pp 395-409, 1998

\section{Women in development: a critical analysis}

\author{
GINA KOCZBERSKI
}

ABSTRACT In the early 1970s a general disenchantment with development efforts in Third World countries led to a search for alternative development strategies and a growing awareness that women, like the poor, were peripheral to the development efforts of major aid donors. In 1972 the United Nations designated 1975 as International Women's Year, highlighting the need to involve women in issues of economic development. During the past 20 years the 'women in development' approach, which seeks to recognise and integrate women in aid policies and programmes, has been incorporated into the aid practice of most development agencies. This paper traces the efforts of large aid agencies over the past two decades to integrate women into their aid programmes and discusses the main limitations and weaknesses of the wID approach.

Many studies of Third World women in the 1990 s indicate that their impoverishment is growing, their work burdens expanding and their status relative to men declining.' Given the optimism of development agencies in the 1970s that a focus on women in their aid programmes would automatically improve their lives, it is pertinent to ask why so little has been achieved. It is recognised that such a question encompasses a broad and complex set of factors that cannot be addressed adequately in a single piece of work. This paper, therefore, narrows the search for possible explanations by examining some of the major aid agencies' efforts to incorporate women into their aid programmes over the past 20 years. These efforts to integrate women into their development plans are generally known as part of the 'women in development' (WID) approach.

The paper begins with a brief overview of the emergence of wID in the 1970s and then considers some of the main problems with this approach. It is argued that WID's attempt to integrate women is based on certain assumptions and arguments that have limited its scope and success. Third World women have been presented in a particular way, with their problems and needs identified by WID 'experts', and their control over the development process firmly restricted. While WID may offer a different approach to 'doing' and 'viewing' development, it is not an alternative approach to mainstream development, as its concepts, strategies and perspectives on development remain welded to the existing Western-dominated development framework.

Gina Koczberski, is at the School of Social Sciences and Asian Languages, Curtin University of Technology, Perth GPO Box U/987, 6845, Western Australia, Australia. 


\section{The emergence of WID}

The idea of integrating Third World women into aid practice first emerged in the USA in the early 1970 s when (mainly female) development practitioners and researchers began pushing for greater representation of women in aid agencies, and demanding that more effort be made by aid organisations to recognise Third World women in their aid programmes. They argued that the aid programmes of the major institutions such as United States Agency for International Development (USAID), the UN, the Food and Agriculture Organisation (FAO), and the World Bank were 'male-biased', resulting in women being ignored and/or disadvantaged by the development process. To support their argument, advocates pointed to the accumulating evidence that Third World women were not only ignored in development plans, but that their economic situation had barely improved over the years. Their pressure on US policy makers resulted in the 1973 Percy Amendment to the US Foreign Assistance Act, which required that USAID's aid programmes 'give particular attention to those programmes, projects and activities which tend to integrate women into the national economies of foreign countries'. ${ }^{2}$ Thus, 'integration' meant women would be incorporated into existing development practice under orthodox notions of development.

'Integration' became the catch-cry of aid agencies in the 1970s and early 1980 s, fuelled, to some extent, by the axiomatic assumption that women's lives would improve once they had been integrated into the development process. While approaches such as 'gender and development' (GAD) and 'women and the environment' (WED) have crept into the discourse of aid agencies, and despite the fact that the concept of integration is now being challenged, integration still features strongly in the rhetoric of most aid agencies. For example, USAID and the World Bank continue to rely on the concepts and frameworks of wID, with its emphasis on integration, and the Australian government's official overseas funding agency, AuSAID, despite recently launching a GAD policy, still maintains that integration of women into its aid programmes is a long-term goal.

Since the mid-1970s there have been numerous initiatives undertaken by aid agencies to correct perceived male-bias in project planning and implementation to further integrate women into development practice. These include various wID policies and programmes, such as special wID units, wID advisors and, over the past decade, gender-analysis training of aid practitioners. For example, AusAID introduced gender analysis training, and gender-awareness raising sessions among staff are now part of staff training. By the early 1990s. AusAID was able to boast that most of its Country Program Managers and desk level officers had undergone gender training. ${ }^{+}$Numerous consultants and wID 'experts' have been recruited, and various WID taskforces established to assist in specific programmes and to provide general staff support for the integration of women into the aid programme.

These integration efforts have increased recognition of women's role in development and encouraged a more 'gender-aware' approach to development planning, but it is suggested that, by holding onto the early concept of integration, the resultant benefits have been limited. One reason for this is that the early concept of integration was (and still is) based largely on the tenet that 
aid practice is male-biased. It is then assumed that, by overcoming male-bias in aid practice, women will automatically benefit more from development efforts. While it is recognised that aid practice was (and remains) male-biased, this paper argues that, by adopting this narrow approach to the problems experienced by women in developing countries, aid agencies and many wID advocates ignored the historical context of development. Also, they ignored some of the inherent problems with the framework of development itself, and failed to acknowledge the specific social and cultural contexts of women's lives.

\section{Historical context of development}

A broader examination of the historical context of development would have revealed other fundamental issues relating to women and the development process. For example, much of the early dealings by developed countries with Third World countries were largely concerned with accessing the developing world's resources and/or introducing the 'primitives' to Christianity. Only partial consideration was given to improving the material welfare of indigenous populations." These relationships with developing countries, often by colonising governments, were generally carried out under a mantle of moral superiority and, at times, condemnation of the indigenous population and their cultural and economic systems.' As Mohanty explains:

Institutionally, colonial rule operated by setting up visible, rigid, and hierarchical distinctions between the colonizers and the colonized. The physical and symbolic separation of the races was decmed necessary to maintain social distance and authority over subject peoples. In effect. the physical details (e.g., racial and sexual separation) of colonial settings were transmuted to a moral plan: the ideal imperial agent embodied authority, discipline, fidelity, devotion, fortitude, and self sacrifice. This definition of white men as 'naturally' born to rule is grounded in a discourse of race and sexuality which necessarily defined colonized peoples, men and women. as incapable of self-government. The maintenance of strong sexual and racial boundaries was thus essential to the distinctions which were made between 'legitimate rulers' and 'childlike subjects'.

Associated with colonialism were fundamental long-term changes to indigenous social and political structures, land tenure, land-use and labour patterns. resulting in the profound disruption of whole societies." Although young men were the main target of colonial governments' interventions (as a cheap labour force), the impacts were often more widespread, with men and women affected in different ways. Women, as the main food producers and nurturers, and in some areas the main generators of wealth, felt much of the brunt of colonialism. Land degradation, enforced relocation, commercialisation of agriculture, labour migration and weakened pre-colonial trading links all put tremendous pressures on women's ability to meet their expected responsibilities. Colonialists (and missionaries) caused, inter alia, a re-definition of indigenous ideologies regarding identity, status, kinship, marriage, residential patterns and gender relations, all of which have had varying and unexpected consequences for women's (and men's) contemporary situations. ${ }^{10}$ These changes, which began in the colonial period, 
continue to be felt by women today. For example, male outmigration from rural areas in many Third World countries was initiated during the colonial period, and has continued into the postcolonial period, adding to the work burdens of women." Thus it was not simply, or solely, a disregard for women by colonial administrators but a total disregard for indigenous economic and social systems, and a belief' among many that the more 'European' indigenous societies became, the better would be the situation for women. ${ }^{12}$

These features of colonialism, in particular the negative perceptions of non-Westerners, were reflected in the devaluing of indigenous social and political systems, and this view continued into the postcolonial period featuring strongly in the development model that emerged after World War II. For example, it was assumed that the development pattern of underdeveloped countries would mirror that of the developed nations of Western Europe and North Amcrica, so aid and development practice was geared to encouraging capital accumulation and overcoming barriers to development such as poor education and inappropriate 'traditional' practices and beliefs. It was believed that underdeveloped countries, plagued by traditional structures and values, would be transformed into modern Western-like industrial nations. This view of 'natural' progression was the basis of modernisation theory, which dominated development ideas between 1950 and 1970. ${ }^{13}$ As noted by Parpart and Marchand, 'the rationale for this progression was provided by colonial (and later neo-colonial) discourses which compared "backward, primitive" Third World peoples and cultures unfavourably with the "progressive' North". ${ }^{4}$ Modernisation theory thus adopted the dichotonisation of colonial discourse to reinforce developed nations' superiority and the negative perceptions of Third World countries: modern/traditional, dynamic/static, progressive/backward and developed/underdeveloped.

Modernisation approaches also gave little consideration to the social and political impacts of economic growth or to the priorities of indigenous communilies, the poor and women. An extensive body of literature now condemns the early modernisation approaches as having failed to deliver real benefits for Third World countries, especially the poor. ${ }^{15}$ Yet, ironically, it was the integration of women into this very framework of modernisation that wID advocates lobbied aid agencies to pursue. While not underestimating the effect of male-bias on women, a singular emphasis on male-bias by early wID proponents oversimplified the situation of Third World women by ignoring the economic, political and social manifestations of historical factors and processes. WID proponents also failed to see that male-bias and the invisibility of women were not separate from general Eurocentric development practice.

\section{Present WID integration efforts}

By disregarding factors other than male-bias that affect women's lives and by ignoring the wider problems associated with mainstream development, a narrow approach to women based on 'integration' emerged in the $1970 \mathrm{~s}$. This concept of integration remains dominant in contemporary WID/GAD practice, and has served to limit the scope and success of WID/GAD practice by the major aid 
organisations. I see three main interrelated problems. They are: i) the institutional construction of integration; ii) the categorisation and portrayal of Third World women: and iii) the privileging and power of integration efforts.

\section{Institutional constraction of integration}

When the goal of integration first emerged in the 1970s, it was based on the view that through integration with national economics, Third World women would begin to participate in the development process. ${ }^{16}$ However, integration by development agencies assumed that women were not already participating in development, thereby concealing and devaluing women's existing roles in informal economic and political activities and household production. Women's work in subsistence production, informal market and community and household work was therefore considered outside the domain of 'development". with the result that a large pant of women's work and daily life was neglected. As Sicoli rightfully remarked at a time when most donor agencies were proudly espousing the importance of integrating women into development: "the role of women in food and agricultural production is already so pervasive in most countries that exhortations to "integrate" women into rural development run the risk of sounding ridiculous'. ${ }^{7}$ By ignoring women's work in informal economic and political spheres, not only was the concept of integrating women flawed from the outset, but it also suffered from the very problem wID practitioners were reportedly fighting against-- that is, the invisibility of women's multiple work roles.

Also, underpinning many of the integration efforts by development agencies was the belief that by increasing Third World women's participation in formal economic and political structures, their status and position in the household and society generally would be enhanced. For example, AusaID documents repeatedly refer to improvements in women's status gained through integration efforts. Similarly, USAID programmes and projects throughout most of the 1980 s promoted activities to integrate women into the economy of their respective countries, thereby improving their status'. While a change in intra-household income patterns may lead to a change in gender relations within a household, it cannot be concluded that this will result in the improved status of women. Indeed, a growing body of literature now questions the simplistic correlation between labour force participation and women's status. ${ }^{19}$ These studies do not question the value of cash income in women's lives, but rather its association with increased female status. Not only is such an equation between income and status predicated upon a dominantly Western view, it also fails to recognise that the factors determining women's status may be culturally specific and multidimensional rather than unidimensional. ${ }^{20}$

Associated with the view that women's status will improve if they move into 'productive employment' is the implicit assumption that women must move from the 'traditional' sector to the 'modern' sector to achieve self-advancement. Such a view is predicated on two main assumptions: the modern sector is socially progressive and a necessary precursor to self-advancement, and 'traditional' work roles are inhibiting to self-development That these assumptions also 
underpin modernisation theory reveals that wID, rather than offering an alternative approach, remains wedded to existing mainstream development frameworks. Further, the close alignment of integration and modernisation means that they share other common problems. For example, both see development as a linear cumulative process, 'traditional' structures as static, and consider anything 'modern' as advanced and 'traditional' as backward. Thus it was accepted that, with the right inputs and incentives, the 'traditional' Third World woman could be transformed into a 'modern' woman, based largely on the image of the Western woman.

Finally, the reliance on modernisation theory justified the argument that women needed to be integrated into development before they could be part of the development process. Modernisation theorists measure development by GDP, which only records formal sector activities. Since women were not seen to be contributing to the formal economy, then they were seen as not contributing to 'development'. In this way Third World women were unproductive, underutilised and, as the World Bank put it, 'in a sense wasted'.21

\section{The categorisation and portrayal of Third World women}

When the spotlight of aid institutions shifted to women, a category was created that standardised and homogenised Third World women. Under this label 'Third World women' all have the same needs and interests, and all are seen as equally disadvantaged. Moreover, Third World women are generally portrayed as universally unproductive, economically inactive, house-bound, tradition-bound, lacking skills and perceived to be relegated to lower-status lasks than men. This (mis)representation of Third World women is evident in the following extracts from AusAID and World Bank documents:

men can seek work in towns, learn skills in the army or go to high school, while women stay at home, or at best, work as maids or at unskilled tasks in industries. Even the latter occupations are usually preferable to low productivity, low reward employment or underemployment at home. ${ }^{22}$

[women's] productivity and capacity to work is often constrained by culture and tradition, which often keeps women homebound, while men go into the outside world. $^{23}$

human capital investments help women break out of traditional molds, move outside the family, behave more like other economic agents. ${ }^{2+}$

new ways should be tried to build the self-confidence mothers need to adopt new behaviors and participate actively in maternal and child health and family planning programmes. ${ }^{25}$

Such views are common in the wID discourse of the major aid agencies and have helped construct an image of Third World women which, as Parpart notes, stands in contrast to the image of the skilled, confident and modern Western women. ${ }^{26}$ The representation of Third World women has recently been explored in the broader development literature and in postcolonial studies. ${ }^{27}$ However, what is of interest here is how aid agencies' construction of 'Third World women 
finds parallels with the colonial discourse on women mentioned earlier. Third World women continue to be portrayed as universally passive, oppressed and ignorant, an image that continues to rely on the binary oppositions used in colonial discourse. ${ }^{2 x}$ Thus, Western stereotypes of Third World women remain unchallenged in the so-called 'alternative' wID approach.

Of serious concern is how this portrayal of Third World women has influenced WID practice. For example the view of Third World women as underutilised and unproductive was particularly evident in the wID efficiency policies of the $1980 \mathrm{~s},{ }^{29}$ and lent support to the notion that women had the capacity to work even harder, or had the free time to participate in a range of WID interventions. The assumption that women were underutilised overlooked one of the major problems facing many Third World women: that of increasing and/or heavy work burdens. While women's workloads vary greatly, accumulating evidence from many parts of the Third World suggests heavy workloads constrain women's ability to provide adequate food and childcare and limit their opportunity to participate in extra-village activities. ${ }^{30}$ Such misconceptions regarding women's work burdens may partly explain the problem observed in some developing countries, where 'development' has simply meant further additions to women's already heavy work burdens, and may help explain the failure of many special women's projects which aimed to encourage women to take on additional tasks such as skills training, poultry projects or other income generating activities."

More importantly, the use of the universal stereotypical image of Third World women as powerless, ignorant and trapped in inferior roles has legitimised an approach that views Third World women in need of help and with little to contribute to development planning. A major feature of integration efforts of the large international aid agencies is that, despite their rhetoric, Third World women have been allowed very little genuine participation. Project planning techniques to integrate women into development projects continue to restrict women's involvement as projects largely remain externally operated and controlled. Rarely is project design, decision making and management devolved to local women. Rather, integration efforts are characterised more by the assumption that, only through the assistance and direction of Western donor agencies can Third World women become productive members of society and achieve self-advancement. Indeed, the modern educated Western female WID 'expert' was created in aid agencies to direct this process. ${ }^{22}$ Thus, integration efforts have not only ignored the realities of women's lives, but Western stereotypes of Third World women have fostered an approach where women are given little control over how, or whether, they desire to be integrated into development projects. This issue of control in development plans is explored further below.

Categorising Third World women as an undifferentiated group fosters a view that they all have the same needs and are equally disadvantaged. Such assumptions ignore the diversity of women's lives and overlook differences in wealth, power and status between women attributable to structural factors like class, caste, clan and marital status. In some situations it may well be that intra-gender differences in work patterns and resource control are just as important, if not more so, than inter-gender differences. For example, in many clan-based soci- 
eties, where the population is characterised more by its social heterogeneity than uniformity, an understanding of women's work patterns and income control, and access to land and other resources, may be better explained by differential access to resources along clan lines rather than by gender differences per se. ${ }^{33}$ It is possible that the reason why wII) practice has all but ignored inequalities between women stems in part from its emphasis on integrating women, and its priority on gender inequalities over other inequalities. These two factors have side-tracked issues of wealth and resource inequalities among women. Yet, by ignoring inequalities between women, wID attempts at encouraging participatory development projects based on the notion of common needs and goals are fraught with problems. ${ }^{34}$ Moreover, wID risks reinforcing and/or accentuating inequalities between women. The danger of WID practice not benefiting poor women was raised in the early stages of the UN Decade for Women. ${ }^{35}$ However, such criticisms have not shifted many donors away from the assumption that all women are equally disadvantaged.

Similarly, some women's groups are more powerful, better networked and positioned than others to receive aid money. My own research has shown that several women's organisations funded by AusAID's wID Fund, were urban-based, and/or well established national or local organisations. with close contacts with external funding bodies. ${ }^{36}$ Representatives of two organisations said they had no difficulties procuring funds from funding bodies. While not detracting from the good work these organisations do, nor ignoring their valuable work with disadvantaged women, AusAID (and other organisations) need to strive to identify and support more isolated rural women's groups or less powerful urban women's groups that may have difficulties securing funds. By recognising diversity among women and women's groups a more equitable allocation of WID resources may be possible.

Valuable insights are to be gained from studies that examine the diversity of situations among women and which provide a more comprehensive and appropriate analysis of women. ${ }^{37}$ Mayoux studied the failure of income-generating schemes in West Bengal and found that the of ficial explanations for the failure of training schemes (constraints on women's movements and the uneconomic basis of handicraft development) were incorrect. Her detailed analysis revealed that the project failed because it was inappropriately designed and targeted. Mayoux identified four different groups of women in the area, whose caste level, work demands and needs differed. The majority of participants in the scheme were from the upper castes, which greatly reduced the scheme's success, as many of these women did not intend to use their new knowledge. As Mayoux remarks $[\mathrm{m}]$ any had taken the courses, for example, in order to gain an advantage in the marriage market or a certificate for professional work. Some had simply wanted the stipend'. ${ }^{38}$ By contrast, the poorer groups of women who, it was officially recognised, would make most use of the scheme. were poorly represented among participants. Mayoux attributed this to administrative barriers and discrimination, and to the design of the scheme, which was unsuitable to the needs of poorer women.

Mayoux's study is significant for several reasons. First, it exposes the myth of Third World women being an undifferentiated group, and shows that not all 
women are impoverished, nor do they face the same set of restrictions on opportunity. Some women are clearly in a more advantageous position than other women (and men) because of their marital, kinship, class or economic status. Second, her study highlights the importance of detailed analysis of the target population in order to design appropriate and suitable development initiatives. Third, it shows how wID activities can discriminate against poorer women if differential status and needs among women in society are not recognised. With continuing reports of increasing poverty and wealth inequalities in Third World countries, the targeting of disadvantaged groups of women appears to be of crucial importance.

It should be noted, however, that by highlighting diversity among women it is not suggested that thare are no sociocconomic characteristics or needs common to most women. Women generally do carry heavier workloads than men and they do comprise most of the poor. ${ }^{36}$ But these generalisations cannot be assumed to apply in a similar way everywhere. More importantly, they should not serve to restrict further analysis at the micro level. While macro assumptions and studies are worthwhile to provide a general view of an issue and/or highlight a particular problem (eg high workloads of women), they can distort our understanding of a particular situation or context if accepted axiomatically. Yet aid practitioners often extend generalisations unquestioningly to different countries, regions, cultures and populations-a problem common to much of development theory and practice. ${ }^{41}$

In many ways therefore, integration has not encouraged donors to go beyond simply recognising women in their policies towards implementing policies and programmes that show evidence of a more detailed analysis and understanding of women's situation in Third World countries. As Tinker notes, studies by development agencies have been 'directed to influencing program directions or policy decisions'. ${ }^{41}$ Very lew efforts are made outside the aid agencies at the village level to discover more about women's needs and concerns.

\section{The privileging and power of the practice of integration}

The narrow focus on integration has also inadvertently led to privileging this objective above broader issues concerning the viability and appropriateness of prevailing WII and mainstream development practice. Many reports document the level of integration in donor aid activities and the reasons for the poor record of integration, but few seriously question the planning techniques used to promote the integration of women, or critically examine the benelits of integration. Hence there is little analysis of whether integration translates into genuine participation of women and this, I would suggest, is attributable to the belief that 'gender sensitive' projects will automatically benefit women. However, such an assumption ignores problems associated with the techniques used to integrate women into projects and the other shortcomings and biases surrounding aid delivery.

While western donor agencies have attempted to incorporate Third World women into development plans, they do little to encourage the participation of women. AusAII), like other international agencies such as USAID, CIISA, and the 
World Bank, has trained many of its staff to apply gender-analysis frameworks/ guidelines to the project cycle ${ }^{42}$ to ensure women are considered in project plans. These frameworks vary, but a common requirement is to collect gender-specific data on the division of labour, access to and control of resources and cultural restrictions on women's activities, and incorporate these data into all stages of the project cycle.

Although gender analysis frameworks require the collection of baseline data, which is commendable and represents an advance on previous gender-blind planning, the usefuless of such frameworks is questionable for several reasons. First, the method is grounded in the concept of women as a separate socioeconomic category, and so underestimates the linkages and interactive nature of people's lives. By compartmentalising women, the framework renders irrelevant the linkages between women's various work roles, kinship relationships and the social, cultural and political systems of which they are a part. Women's work activities, their access to resources and their needs are not isolated fragments, rather they are intricately embedded within the communities in which they live. To ignore these linkages predisposes simplistic and unrealistic analyses and constructs images far removed from reality.

In addition, by compartmentalising women, gender analysis techniques continue with development planning's reductionist approach in isolating development 'problems' that need 'fixing'. This categorising of problems is typical of much of development practice, which as Porter et al point out, is based on the Western rationale that:

all aspects of life can be isolated into bits, whether they be complex agro-ecosystems or traditional knowledge systems. Following on from this it assumes that these bits may be removed, manipulated and then sometimes re-inserted into the culture, in order to bring about desirable outcomes in a controlled manner. ${ }^{23}$

It is this issue of control that is the most problematic with the gender-analysis framework, for it offers few opportunities for women to define and control local development efforts. ${ }^{44}$ Rather, the techniques tend to promote external control of development plans and project design. The project cycle, of which the gender analysis framework is a part, is comprised of a set of rigid 'control-orientated' planning procedures adopted by AusAID and other major donor agencies to overcome the perceived complexities and uncertainties of development. As Rondinelli notes:

international assistance organizations and central planning and finance ministries in developing countries adopted more detailed and rigid planning procedures in the late 1960s and early 1970s in an attempt to anticipate and eliminate many of the problems that had plagued development in the past. But in attempting to apply more comprehensive and detailed controls, planners often generated new conflicts and problems.

Control-orientated planning, or 'management science' as Crittenden \& Lea label it $^{\text {th }}$ is reflected in the use of log-frame analysis, cost-benefit analysis, elaborate activity/project cycles and more recently, gender analysis frameworks. All these management tools attempt to exert greater control over project outcomes, for it 
is assumed that, once all the components of the project environment are known and controlled, the desired outcome will result. ${ }^{47}$ While these planning techniques may not be inappropriate in themselves, they may encourage a view among practitioners that more refined, sophisticated and rigid frameworks will enhance aid effectiveness through tighter controls. For this reason, these planning techniques are increasingly being criticised as inappropriate planning tools. ${ }^{48}$

With this type of planning the overriding objective becomes one of 'managing' the 'problem'. For example, an examination of AusAID's internal WID reports monitoring the integration of women into the organisation's development plans, reveals greater concern with how wID can be better managed or administered than with how AusAID can learn more about women's lives at the local level. Their 1992 wID Review reflects this emphasis on improving aid management as many of the recommendations generally relate to tightening project and program procedures. ${ }^{49}$ In its recommendations to improve the integration of women in bilateral aid projects the report suggests this can be achieved through:

developing screening mechanisms in project processing: ongoing staff training programmes for staff administering projects: developing more targeted wID training for staff... raising of individual management capacity in addressing WID in economic infrastructure sectors; providing wID briefing for project management and consultants: and ensuring critical wID input into project processing. ${ }^{50}$

Similarly last year in a major review of AuSAID's aid programme, recommendations were made to introduce regular gender audits, reassess wID monitoring tools and allocate more staff to gender monitoring and staff training to strengthen the integration of gender concerns in the aid programme. ${ }^{51}$ Thus, the assumption that greater control over the planning process will lead to more effective aid delivery is well entrenched in wID initiatives. In other words, the 'women problem', identificd and constructed by aid agencies, can be solved through more rigid planning. No-one has yet challenged this assumption and hence the view that Western nations know how to solve the problems of Third World women is reinforced. More disturbing, perhaps, is that, by controlling development practice, Western donors continue to place themselves in the position of 'experts' who hold the solutions to the problems of Third World women. As indicated above, it was out of the efforts to integrate women into development that the skilled Western wID 'expert' arose-considered competent in project cycles and gender analysis techniques, and in possession of the required knowledge to improve the lives of Third World women. Third World women play only a secondary role in this framework.

\section{Conclusion}

At the beginning of this paper I argued that the 1970 push to integrate women into development had limited success because it was based largely on the narrow tenet that aid practice was male-biased. From this basic premise it was assumed that a more gender aware or gender-sensitive approach to development practice would be sufficient to deliver economic and social benefits to women. However, 
as I have suggested in this paper, one of the main problems of WID relates to the way the major aid agencies have clung to this early concept of integration. By concentrating primarily on integrating women into prevailing development practice, WID/GAD does not really offer an alternative approach to mainstream development practice, as many of its assumptions, strategies and notions of 'development' remain firmly rooted in existing development frameworks. The problems found in mainstream development practice, such as misrepresentation and over-generalisation, the use of rigid project frameworks, and the limits placed on Third World people to define and control their own lives, remain in the WID/GiAD approach.

The issue of participation and control over development is of major concern and, as Boulding remarked, rather than questioning how women can be integrated into development, the question should have been what do women want "? Her remark reveals how Third World women were given little say in the way development initiatives were planned in the early stages of the UN Decade for Women. It is somewhat disturbing that Boulding's comment continues to ring true today as project planning techniques continue to restrict women's involvement in a development process where projects largely remain externally operated and controlled. In the current integration efforts of large donors there is little emphasis on harnessing indigenous knowledge and expertise, and opportunities for women to design and manage their own projects remain limited.

The need to allow indigenous people greater control over development is not new and has long been recognised, especially among non-governmental organisations (NGOS). ${ }^{53}$ Although major aid organisations have increased funding of projects designed and implemented by local women's groups over the past 10 years, it is still only a small part of their aid programme. For example, AusAID's wID Fund, which began in 1984 and was the main scheme to support small-scale innovative projects designed and implemented by local women's groups, had a budget of Aus $\$ 3$ million. This represented a tiny proportion of the total aid budget of just over $\$ 1500$ million in 1994/95. In 1996 the wiD Fund was abolished in a rationalisation of AusAID's NGO programmes, without any evaluation of the effectiveness of the scheme. Although other avenues are open for indigenous women's groups to apply directly to AusAID for project funding, these are extremely limited. Finally, although efforts to allow women more control over development initiatives are being addressed by some of the major aid donors, further research, discussion and negotiation relating to the control of projects is required among aid practitioners, aid organisations and local people, particularly given the problematic nature of participatory development.

\section{Notes}

I am grateful to colleagues in the School of Social Sciences and $\Lambda$ sian Languages, Curtin University of Technology for helpful comments on a draft of this paper.

E M Rathgeber, Integrating gender into development: research and action agendas for the 1990s", Journal of Deteleping Socicties, VIII, 1992, pp 11 29; United Nations Population Fund, Notcbook, Populi, 20(2), 1993, p 16; and United Nations Development Programme, Human Delelopment Report 1996, New York: Oxford University Press, 1996 
Quoted in I Tinker. 'The making of a field: advocates, practitioners, and scholars', in Tinker (ed), Persistent Inequalitios, Woman and World Development, Now York: Oxford University Press, 1990, pp 27.53 (emphasis added).

'M Mies, Gender and global capitalism', in L Sklair (ed), Captalism and Development. London: Routledge, 1994, pp 107 122; G (howdhry, 'Engendering developmen? Women in Development (wI)) in international development regines", in M Marchand \& J Parparl (eds), Feminism, Pestmodernism, Development, London: Routledge, 1995, pp 26 41; J Parpart. 'Deconstructing the development "expert": gender, development and the "vulnerable groups", in M Marchand \& J Parpart (eds), Feminism, Postmodernism, Develspment, London: Routledge, 1995, pp 221-243; and G Koczberski, 'From Mexico to Beijing: "Women in Devclopment" twenty five years on', Australian Geographical Sudies, 34(1), 1996, pp 138 148.

4 Australian Intemational Development Assistance Burcau (A1DB), Australia's Overseas Aid Program 199/-92. Budget Related Paper No 4, 1991, Canberra: Australian Publishing Service, 1991

Australian Intemational Development Assistance Burcau, Women in Development, Gisideines and Proce". durex, Canberra: Australian Government Publishing Service, 1984; M R Planner \& M W Ward, The

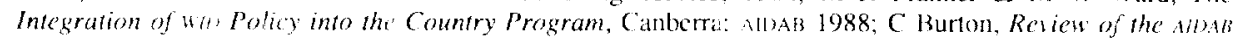
Women in Development Fund 1984-1990, Parl I: Background Review, Draft, Canberra: AlDAB, 1988; M Johnson \& A Johnston, Gender Analysis Team Finat Repon, Canberra: ABAB, 1991; Australian Intemational Development Assistance Bureau, Women Moving Fortara. Revicw of the integration of women in development policy into Australian International Developmen Assistance Burcau progranmes, Executive Summary, Canberra: Australian Govemment Publishing Servec. 1992; and Aussur. One Clear Objective. Poterty Reduction Through Sustainable Development. Report of the Committee of Retiew, Canberra: Australian Government Publishing Service, 1997, pp 242 243.

"D Conyers \& P Hill, An Introduction of Development Planning in the Third World, Chichester: Wilcy, 1984; D Johnston, 'Constructing the periphery in modern global politics', in C Murphy \& R Tooze (eds). The New Intonational Political liconomy. Boulder, CO: Lyme Reinnor, 1991, pp $149-169$.

M Hetherington, British Paternalism and Africa 1920-1940, London Frank ('ass. 1978; P Blaikic \& I1 Bronkfield, 'Colonialism. development and degradation', in Blaikie \& Brookfield (eds), Land De'gradation and Socie't, London: Methuen, 1987, pp 100121 ; J de Croot. 'Conceptions and miseonceptions: the historical and culural context of discussion on wonen and development in H Afshar (ed), Women. Development and Surival in the Third World, New York: Longman, 1991, pp 107 135; M llavinden \& D Meredith. Colonialism and Development: Briain and its Tropical Colonies 1850-1960, london: Routledge, 1993; and M Dhaouadi. 'Capitalism, global humane development and the other underdevelopment', in 1. Sklair, Capitalism and Development, 1994, pp 140164.

C Mohanty. 'Under Westem eyes: feminist scholarship and colonial discourses, in C Mohany, A Russo, \& L Torress (eds), Third World Wome'n and the Politics of Feminism, Bloomington, in: Indiana Liniversity Press, 1991, pp 51 80.

" If Brooktield, Colonialism, Dewlopment and Independente. The Case of the Melanesian /stands in the South Pacific. Cambridge: Cambridge University Press, 1972; M Jolly \& M Macintyre (eds). Family and (iender in the Patific. Domestic Contudictions and the Colonial Impar, Cambridge: Cambridge University Press, 1989; and D Porter, B Allen, \& G Thompson, Development in Practice. Paned With Sicod Intentions, london: Routledge, 1991 .

"For examples from the South Pacific region see Jolly \& Macintyre, Family and Gender in the Pesifie. II Ware, Women. Demography and Development, Canbera: Australian National Universiy, Development Studies Contre, 1981; Blaikie \& Brookficld, Land Degradatim and Sociefy.

Ware, Women. Demography and Development.

"See W W Rostow. The Stages of Economi Growth: A Non Communts Manife bo, Cambridge: Cambridge University Press, 1960

17 J Parpart \& $M$ Marchand, 'Exploding the canon: an introductionconclusion', in Marchand de Parpart, Feminism, Postmodernism, Development.

SSe for example, A lloben, 'Anthropologists and developmen:', Annual Revieu of Anthropology, 11. 1982, pp 349 75; R Chambers, Rural Development: Putting the Lest First, London: Longman, 1983.

6. E. Boulding, 'Integration into what? Reflections on development planning for women', Cemergence $13(1-2), 1980$, pp 5059.

'Cited in $1 \mathrm{M}$ Spiro. 'Women farmers and traders in Oyo state, Nigeria-"-a case study of their changing roles', in J Henshall-Momsen \& J Towrsend (eds), (iegraphy of Gendor in the Third World. London: State University of New York Press, 1987. pp $173-191$.

's R Dixon, 'Assessing the impact of development projects on women' ND Program Evaluation Discussion Paper No 8, lsallo, 1980, p 4; A Carloni, Women in Dewelopment: w's Experience, 1973-1085. Vol 1 Synthesis Paper, ais Program Evaluation Report No 18, 1 \$ A11, 1987

19 J Bruce, 'Homes divided', World Devclopment, 17(7), 1989, pp 979 92; A M Faulkner \& V A lawson, 'Employment versus enpowerment: a case study of the nature of women's work in Ecuador', Journal of Developing Studies, 27(4), 1991, pp 16-47, 1 Papps, "Women, work and well-being in the Middle East: an outline of the relevant literature'. Journal of Development Studies, 28(4), 1992. pp 595016. 
27) Sce N McDowell, 'Complementarity: the relationship between female and male in the East Sepik Village of Bun, Papua New Guinea', in D O'Brien \& S Tiffany (eds), Rethinking Women's Roles. Perspectives from the Pacific, Berkeley, CA: University of California Press, 1984, pp 32-52; F Errington \& D Gewertz, Cultural Alternatives and a Feminist Anthropology. An Analysis of Culturally' Constructed Gender Interest in Papua New Guinea, Cambridge: Cambridge University Press, 1987; and M Strathem, The Gender of the Giff. Problems with Women and Problems with Socicty in Melanesia, Berkeley, CA: University of California Press, 1990.

2. World Bank, Women in Development. Issues for Economic and Sector Analysis, Working Paper, Women in Development Division, Population and Human Resources Department, Washington, 1989, p v.

2z Australian International Development Assistance Bureau, Report of the Commitlee to Review the Australian Olerseas Aid Program, Canberra: Australian Government Publishing Service, 1984. The report was part of a major review of the Australian aid programme, and had a considerable impact on the types of programmes and policies later introduced by AusAls.

2 World Bank, Women in Development.

2.4 Ibid, p 38

25 Ibid, p 39

26. I Parpart. 'Who is the other'? A postmodern feminist critique of women and development theory and practice', Development and Change', 24, 1993. pp 439-464.

27 A Ong, Colonialism and modernity: feminist representations of women in non-Western societies', Inscriptions, 3/4(2), 1988, pp 79-93; G Spivak, 'Can the subaltem speak?', in C Nelson \& L Grassberg (eds), Marxism and the Interpretation of Culture, Urbana \& Chicago, IL: University of Illinois, 1988, pp 271 313: T Minh-ha, Woman, Native, Other, Bloomington, IN: Indiana University Press, 1989; I Schick, 'Representing Middle Eastern women: feminism and colonial discourse', Feminist Studies, 16(2), 1988, pp 345-380; Mohanty, 'Under Western eyes'; and G Koczberski, 'Women in development: an examination of the ideology, policy and practice', unpublished MA thesis, University of New England, 1993.

${ }^{2 x}$ For a discussion on similarities of WID discourse and colonial discourse sec $F$ Apflel-Marglin \& S Simon, 'Feminist orientalism and development', in W llarcourt (cd), Feminist Perspectives on Sustainable Development, Iondon: Zed Books, 1994, pp 11-25; and Mohanty, 'Under Western eyes'.

26 The wil) efficicncy policy aims to cnsure development is efficient and effective by increasing women's economic participation and their productivity in the formal cconomy. Low education levels and unproductive technologies are identificd as the main constraints affecting women's conomic participation. Efficiency policies are closely associated with structural adjustment programmes.

"P Soysa, 'Women and nutrition', World Review of Nutrition and Dietetes, 52, 1987, pp 1-70; N levine, 'Women's work and infant feeding: a case from rural Nepal', Ethnology, 27(3), 1988, pp 231-251; A Mehretu \& C Mutambirwa, 'Gender differences in time and energy costs of distance from regular domestic chores in rural Zimbabwe: a case study in the Chiduku communal area'. World Development 20(11). 1992, pp $1675-1683$

See Tinker, Persistent Inequalities, pp 27-53; H Barrett \& A Browne, 'T'ime for development? The case of women's horticultural schemes in rural Gambia', Scottish Geographical Magazine, 105(1), 1989, pp 4-11: and L. Mayoux. 'Beyond naivety: women, gender inequality and participatory development', Development and Change, 26(2), 1995, pp 235-258.

SSe Parpart, Deconstructing the development "expert"

Sce, for example, G Koczberski \& G Curry, 'Women and migration: a case study from a rural lowland village in Papua New Guinea', in J lairhurst, J Booysen, \&. P Hattingh (eds), Migration and Gender: Place, Time and People Specific, Pretoria: International Geography Union on Gender and Migration, University of Pretoria Press, 1997, pp 183-198.

${ }^{24}$ Mayoux, 'Beyond naively'.

II Papanek, 'The differential impact of programmes and policies on women in development', in R Dauber \& M L Cain (eds), Women and Technological Change in Developing Countries, Boulder, CO: Westvicw Press, 1981, pp 215-226; A Bandarage, 'Women in development: liberalism, Marxism and Marxist feninism', Derelopment and Change, 15, 1984. pp 495-515.

3r. Koczberski, 'Women in development'.

: See for example, M Mies, The Lace Makers of Narsapur: Indian Housewives Produce for the World Market, London: /ed Press, 1982; L Mayoux. 'The poventy of income generation: a critique of women's handicraft schemes in India', in $\mathrm{T}$ Wallace \& $\mathrm{C}$ March (eds), Changing Perceptions. Writings on Gender and Development, Oxford: Oxfam, 1991, pp 219-235; M Warner, R Al-Hassan \& J Kydd, 'Beyond gender roles? Conceptualising the social and economic lives of rural people in sub-Saharan Afraca, Development and Change, 28, 1997, pp 143-168.

"3ayoux, 'The poverty of income generation', p 226.

*3) United Nations Development Programme, Human Development Report 1996, New York: Oxford University Press, 1996.

4) $\mathrm{T}$ Svensson, 'Theories and mythologies of the Third World', in $\mathrm{M}$ Morner \& $\mathrm{T}$ Svensson (eds), The Transformation of Rural Society in the Third World, London: Routledge, 1991. 
${ }^{71}$ Tinker, 'A context for the field and the book' in Tinker, Persistent Inequalitie's, p 5.

12 The 'project cycle' is a planning tool used by Ausali) (based on the World Bank's project cycle) that guides the project manager through each stage of the project from identification, appraisal, implementation, through to final evaluation of the project.

${ }^{13}$ Porter et al, Development in Practice.

${ }_{44}$ This issue of control is taken further by Escobar, who critically examines the history of development planning and sees it as a means of maintaining dominance and power over Third World countries. A Escobar, 'Development planning', in S Corbridge (ed), Development Studies. A Reader, London: Edward Amold, 1995, pp 64-77.

${ }^{45}$ D Rondincli, Development Projects as Policy Experiments. An Adaptive Approach to Development Administration, London, Methuen, 1993.

th R Crittenden \& D Lea, 'Geographers and 'logical' development practice: the smallholder market access and food supply programme in Papua New Guinea', Applied Geography, 12, 1991. pp 47-64.

${ }^{47}$ Rondinelli, Development Projects as Policy Experiments; and Porter et al, Development in Practice.

${ }^{1 *}$ Rondinelli, Development Projects as Policy Experiments; R Crittenden \& D Lea, 'Geographers and 'logical' development practice: the smallholder market access and food supply programme in Papua New Guinea', Applied Geography, 12, 1991, pp 47-64; and Porter et al, Development in Practice.

44) Australian Intemational Development Assistance Bureau, Women Moving Forward.

Ibid, pp 3-4.

"Ausall, One Clear Objective, pp 244-245.

${ }^{52} \mathrm{E}$ Boulding, 'Integration into what? Reflections on development planning for women', Convergence, 13(1-2), 1980, pp 50-59.

${ }^{3}$ R Chambers, Rural Development; P Richards, Indigenous Agricultural Revolution, London: Hutchinson, 1985; and M Edwards, "The irrelevance of development studies", Third World Quarterty, 11, 1989. pp $116-135$

\title{
Islam and Christian-Muslim Relations
}

\author{
EDTTORS \\ John L. Esposito, Georgetown University. Washington, DC, USA and \\ Jorgen S. Nielsen, Selly Oak Colleges, Birmingham, UK
}

Islam and Christian-Muslim Relations (ICMR) was launched in June 1990 and has been hailed by scholars of Islam, Christianity and religion in general, as well as by social scientists, educationists, community and religious leaders. ICMR provides a forum for all those who wish to cnhance their critical appreciation of the two religious traditions on historical, empirical, ideological and theoretical issues. Since its new partnership with the Center for Muslim-Christian Understanding at Georgetown University, Washington DC commenced in 1996, the journal has broadened its scope to encompass issues concerning Christian-Muslim relations in politics and international affairs.

Volume 9, 1998, 3 issues. ISSN 0959-6410

\begin{tabular}{|c|c|c|}
\hline & $\begin{array}{c}\text { Carfax Publishing Limited } \\
\text { PO Box } 25 \cdot \text { Abingdon } \cdot \text { Oxfordshire OX14 3UE } \cdot \text { UK } \\
\text { Tel: }+44(0) 1235521154 \cdot \text { Fax: }+44(0) 1235401550\end{array}$ & \\
\hline CAREAX & E-mail:sales@carfax.co.uk·WWW: http://www.carfax.co.uk & CARFAX \\
\hline
\end{tabular}

